\title{
SENSORY EVALUATION OF VARIOUS LAMB MEAT FOODS BY JUDGING CONSUMERS
}

\author{
S. KuKOvics* and T. NÉmeth \\ Research Institute for Animal Breeding and Nutrition, 2053 Herceghalom, Gesztenyés u. 1. Hungary
}

(Received: 6 November 2012; accepted: 24 February 2013)

\begin{abstract}
Four kinds of lamb meat foods (Wiener sausage, ham, roasted meat, and roasted leg) were developed based on 8 different genotypes to improve lamb meat quality and quantity, and to study the differences among them. The stringiness, flavour, and odour of the products were judged in food sensory evaluation by a total of $265(60 \%$ male and $40 \%$ female) randomly selected consumers. In stringiness and flavour five (from 1 to 5), and concerning odour three (from 1 to 3 ) categories were created according to decreasing quality. The consumers represented different age groups: below 20 years, between $21-30,31-40,41-50,51-60,61-70$, and above 70 years. The groups of consumers were involved in sheep farming, other animal farming, other agriculture sector, industry, catering, education, other service; administrative department of the state, were students, and others. Analyses of variance were calculated to estimate the effects of the genotype of lamb, the gender, age, and occupation of judging consumers on the sensory evaluation of the meat foods. In conclusion, new lamb meat foods were highly appreciated by consumers, who made definite distinctions among genotypes according to flavour, stinginess, and odour. There were significant interactions between gender, age, and occupation of consumers as well as sensory evaluation of various lamb meat foods.
\end{abstract}

Keywords: lamb meat food, genotype, sensory evaluation, consumer, gender, age, occupation

In Hungary, lamb and mutton meat are dominantly consumed as stew/ragout, sometimes as soup, but other kinds of dishes are not really made. The average lamb/mutton meat consumption is $300 \mathrm{~g}$ per year per person. In the down-towns and in the capital the lamb and/ or mutton meat consumption is not typical; however, it is available in the supermarkets. The traditional lamb or mutton dishes are cooked in the country (as a kind of stew), often in festivals, animal fairs, food exhibitions. As people are prejudiced against the mutton meat because of its fatty flavour, the meat must be altered to satisfy the consumer preferences and/ or improve the knowledge about this kind of meat.

There is a strong correlation between sensory attributes. Because the tenderness is a major factor for consumer acceptability of meat, the low or high score for tenderness attract the low or high score for flavour, juiciness, and overall acceptability (BuNCH et al., 2004). The moistness is in high correlation with sustained juiciness, while adhesiveness and chewiness highly correlate with hardness (GorRaIz et al., 2000). Juiciness is related to both the capacity of the muscle to release its constitutive water (initial juiciness) and the infiltrated fat content (sustained juiciness) (DRYDEN \& MARCHELlo, 1970); however, initial juiciness and moisture content are in negative correlation (HofFmAn et al., 2003).

The sensory values and quality of lamb meat are influenced by several factors. As the breed can influence the acceptability of meat, several studies were made on comparing the meat of wool and hair sheep breeds (FAHMY et al., 1992; HorCADA et al., 1998; BRzostowski et al., 2004; TeIXeIRA et al,. 2005). The hair sheep (especially St. Croix lambs) meat were preferred to the meat of wool sheep (BuNCH et al., 2004) and coarse-wool breeds (DUCKETT \&

\footnotetext{
* To whom correspondence should be addressed.

Fax:+3623319133 /ext. 120; e-mail: sandor.kukovics@atk.hu
} 
Kuber, 2001). The Callipyge phenomenon was clearly found less acceptable than the nonCallipyge breeding groups using a trained panel for sensory analysis. Breeding groups had a greater impact on tenderness than on flavour or juiciness (Bunch et al., 2004). The lamb from fine-wool breeds had more intense flavour than coarse-wool breeds (DUCKET \& KUBER, 2001), while prolific breeds (Romanov and Finnsheep) had a higher percentage of off-flavour than a standard meat-type breed, such as the Suffolk breed (FAHмY et al., 1992). Crossbreeding influenced only some of the sensory parameters. The meat of crossbred lambs had significantly higher tenderness and juiciness than the meat obtained from purebred Pomeranian lambs (Brzostowski et al., 2004). According to Hoffman and co-workers (2003), breed did not have a significant effect on sensory quality (aroma, sustained juiciness, first bite, residue, and flavour) of lamb meat, except for Dormer $\times$ South African Mutton Merino lambs, which showed a significantly higher initial juiciness compared to Suffolk $\times$ Merino lambs.

Meat flavour is also impacted by the nutrition of the lambs before slaughter (MELTON,1990; FISCHER et al., 2000; Gorraiz et al., 2000; SAÑUdo et al., 2000; Bunch et al., 2004). Intensity of flavour is increased with grazing on white clover, alfalfa, and certain crop aftermaths. Grain feeding alone or supplemented while on pasture typically produces lamb with more acceptable flavours than on pasture alone. However, the extent at which flavour intensity is altered depends on the type of forage and grain consumed. Supplementation of diets with oils or protected fats increases PUFA content and results in increased intensity of off-flavours associated with autooxidation of PUFA during cooking (DUCKETT \& KUBER, 2001).

Since the consumer preferences and cuisine traditions are various, the meat flavour is also different according to the slaughter weight (HorCADA et al., 1998; BERIAIN et al., 2000). Lightness decreased with increasing live weight and the light lambs had higher yellow index than the heavier lambs. The heavy carcasses had more flavour intensity than the light ones (TEIXEIRA et al., 2005).

With the age (in relation with the weight) of lambs at slaughtering the likelihood of offflavour in meat of male lambs increases. Seven-month-old male lambs had more undesirable meat characteristics compared to the three-months-old male lambs (RousSET-AKRIM et al., 1997). Only small differences were observed in palatability of meat from rams and wethers weighting below $55 \mathrm{~kg}$ body weight and slaughtered before the age of six months (NOTTER et al., 1991).

The sex of lambs can also alter the flavour of the meat. In Norway, significant offflavours of male lambs meat were found compared to female lambs, when the slaughtering took place before the mating season (in October/November) or after the mating season (in March/April). Even when lambs were slaughtered in mid-September, minor differences between genders were still found (MusHi et al., 2008). On the contrary, there is a tendency to a higher intensity in sour odour in meat from female lambs compared to meat from male lambs and a tendency to a higher intensity in rancid odour in meat from male lambs compared to meat from female lambs (Lind et al., 2011).

Consumers could distinguish lambs according to their origin and their preferences. Dominantly well trained panellists were making sensory examinations of various meat (including lamb meat), but even on family level the not trained panellist could make differences among breeds of lamb according to their preferences. The cultural background and previous experiences or knowledge affect the preferences of the panellist (WARD et al., 1995; SAÑUdo et al., 1998; 2000).

Although the sex of the lamb has significant effect on meat quality, the acceptance of the lamb meat according to gender of the panellist has not been studied. Also limited information 
is available on the effect of age and the occupation of the panellist on the ratings of sensory attributes of lamb meat.

The main aim of this present study was to examine the acceptance of various lamb meat foods by the untrained panellists, who are the real consumers. The other aim of this study was to investigate the ability of the panellist to distinguish between breeds; as well as the effect of gender, age, and occupation of panellists on the sensory evaluation.

\section{Materials and methods}

\subsection{The animals}

Lambs belonging to different genotypes were indoors fattened ad libitum on pelleted feed with limited grass hay supplement. Transylvanian Racka ewes were harem mated by rams of the following terminal breeds: Transylvanian Racka, British Milksheep, Charollais, Ile de France, German Blackhead Mutton Sheep, German Mutton Merino, Suffolk, and Texel. Forty lambs (20 males +20 females) per genotypes were fattened up to $27-30 \mathrm{~kg}$ of live weight category, on approximately 60 days after weaning at $16-18 \mathrm{~kg}$ body weight. Half of the lambs (10-10 male and female) from each group were slaughtered.

\subsection{The preparation of samples}

After the S/EUROP classification, bisection, dissection, boning, and measuring the meat were handled by genotypes. Samples for different products were separately packed into plastic bags, and after slow cooling they were frozen and kept at $-20^{\circ} \mathrm{C}$ temperature until processing.

The meat was gradually de-frosted and three products were developed and manufactured at Biharnagybajom Slaughterhouse and Meat Processing Ltd: Wiener sausage (8 kinds); cured, smoked, and cooked ham ( 8 kinds); kitchen ready seasoned, cured, sliced, and roasted lamb meat ( 8 kinds). The manufacturing process was similar for all genotypes.

The prepared meat products were aged for three days, four weeks, and two days in the previous order. The hams were smoked for $24 \mathrm{~h}$ following four weeks of aging, and after two days of rest they were cooked, then cooled down and kept at $8{ }^{\circ} \mathrm{C}$ until presentation. The developed products were promoted and tasted at the Farmer Expo Exhibition (Debrecen). The Wiener sausages were boiled only before sensory study and kept served at $40{ }^{\circ} \mathrm{C}$. The seasoned and sliced lamb meats were roasted at $170{ }^{\circ} \mathrm{C}$ right before sensory test and offered at $40{ }^{\circ} \mathrm{C}$ to the participants of the sensory panel. The lamb hams were warmed at ambient temperature and served at $18^{\circ} \mathrm{C}$.

For the preparation of the whole roasted lamb leg (restaurant style), two heads of purebred Transylvanian Racka, British Milksheep $\mathrm{F}_{1}$, Charollais $\mathrm{F}_{1}$, and Texel $\mathrm{F}_{1}$ were slaughtered two days prior presentation and sensory study, and prepared in the oldest and most famous restaurant in Debrecen (Arany Bika Restaurant). The legs were kept at $60{ }^{\circ} \mathrm{C}$ until offer to sensory evaluation.

Samples $(3.0 \times 1.5 \times 2.0 \mathrm{~cm}$ cubes $)$ were made from various products and put on a preheated plate. These samples were coded with a randomized three-digit number. 


\subsection{The sensory panel and examination}

The sensory panels were created from visitors of the abovementioned exhibition. The first three products were sensory examined every day around midday by 80 (44 male+36 female - Wiener sausage); 82 (50 male+32 female - cured, smoked and cooked ham); and 64 (37 male +27 female - cured, seasoned, sliced and roasted lamb meat) persons. The fourth product was qualified one hour before the official reception of exhibition by 39 ( 27 male+12 female - whole roasted lamb leg) panellists. All panellist tasted 8 different pieces (by genotype of lambs) of only one product (sausage, or ham, or roasted meat, or roasted leg).

The members of panels were informed on the quality examination of various meat products. The panellists individually filled in a form including some identifier data about the tasted product (type, number) and about themselves (gender: male/female; age: under year 20 , between $21-30,31-40,41-50,51-60,61-70$, above 70; occupation: sheep farmer/ shepherd, other animal farmer, other agriculture, industry and/or catering, education, student, administrative department of the state, other profession).

Three traits were requested to be rated as follows: stringiness (1 very soft, 2 soft, 3 neither soft nor stringy, 4 stringy, 5 very stringy), flavour (1 very delicious, 2 delicious, 3 satisfying, 4 not satisfying, 5 foul flavour), and odour (1 perfect, 2 sufficient, 3 insufficient - based on the intensity of lamb meat aroma).

Analyses of variance were calculated to estimate the effects of lamb genotype and the age, occupation, and gender of the judging consumers on the sensory evaluation of various meat foods.

\section{Results and discussion}

The three developed new lamb meat products and the whole roasted lamb leg made in restaurant style were evaluated separately.

\subsection{Wiener sausage (Table 1)}

The gender had definite effect on the judgements concerning stringiness, flavour, and odour of the sausages. Reasonable deviations were observed among genotypes. For stringiness women gave higher points, which means worse scores, than men, except for British Milk sheep $F_{1}$, which sausage was the least stringy by women, while men gave the best (lowest) score to the sausage made from Charollais $\mathrm{F}_{1}$ lambs. The lowest (best) score for flavour were given to Suffolk $F_{1}$ by men, and to Texel $F_{1}$ by women, who also found its odour the best. On the contrary, men gave the lowest (best) odour score to the sausage made from Transylvanian Racka lambs. Greater degree of differences were observed concerning stringiness and flavour among genotypes, while smaller deviations were found in odour according to the gender of panellists.

Breed differences were found in toughness, odour, and stringiness in several studies (SAÑUdo et al., 1997; FishER et al., 2000; TEIXEIRA et al., 2005), so our observations confirmed their findings.

The occupation definitely influenced judgements. People working in the administrative department of State found the sausage the most stringy, while farmers found it the softest. In flavour there was strong difference between scores given by shepherds and most of the other occupations. However, concerning odour, judgements of panellists working in the industry, 
Table 1a. Sensory evaluation of Wiener sausage

\begin{tabular}{|c|c|c|c|c|c|c|c|c|c|}
\hline & \multirow[b]{2}{*}{$\begin{array}{l}\text { Gender of } \\
\text { consumer } \\
\text { (n) }\end{array}$} & \multicolumn{8}{|c|}{ Breed } \\
\hline & & $\begin{array}{c}\text { Tran- } \\
\text { sylvanian } \\
\text { Racka }\end{array}$ & $\begin{array}{c}\text { British } \\
\text { Milk- } \\
\text { sheep } \\
\mathrm{F}_{1}\end{array}$ & $\begin{array}{c}\text { Charollais } \\
\mathrm{F}_{1}\end{array}$ & $\begin{array}{c}\text { Ile de } \\
\text { France } \\
\mathrm{F}_{1}\end{array}$ & $\begin{array}{c}\text { German } \\
\text { Blackhead } \\
\text { Mutton } \\
\text { Sheep } \\
\text { F }_{1}\end{array}$ & $\begin{array}{c}\text { German } \\
\text { Mutton } \\
\text { Merino } \\
\mathrm{F}_{1}\end{array}$ & $\begin{array}{c}\text { Suffolk } \\
\mathrm{F}_{1}\end{array}$ & $\begin{array}{c}\text { Texel } \\
\mathrm{F}_{1}\end{array}$ \\
\hline \multirow[t]{2}{*}{ Stringiness } & Male (44) & $2.55^{\mathrm{a}}$ & $2.55^{\mathrm{a}}$ & $2.23^{\mathrm{b}}$ & $2.59^{\mathrm{a}}$ & $2.57^{\mathrm{c}}$ & $2.66^{\mathrm{c}}$ & $2.50^{\mathrm{a}}$ & $2.30^{\mathrm{b}}$ \\
\hline & Female (36) & $2.58^{\mathrm{a}}$ & $2.36^{\mathrm{b}}$ & $2.47^{\mathrm{b}}$ & $2.61^{\mathrm{a}}$ & $2.72^{\mathrm{c}}$ & $2.75^{\mathrm{c}}$ & $2.56^{\mathrm{a}}$ & $2.56^{\mathrm{a}}$ \\
\hline \multirow[t]{2}{*}{ Flavour } & Male (44) & $2.09^{\mathrm{a}}$ & $2.30^{\mathrm{b}}$ & $2.14^{c}$ & $2.09^{\mathrm{a}}$ & $2.18^{\mathrm{c}}$ & $2.16^{\mathrm{c}}$ & $2.02^{\mathrm{a}}$ & $2.09^{\mathrm{a}}$ \\
\hline & Female (36) & $2.11^{\mathrm{a}}$ & $1.86^{\mathrm{b}}$ & $2.14^{\mathrm{a}}$ & $1.94^{\mathrm{c}}$ & $1.97^{\circ}$ & $1.89^{\mathrm{b}}$ & $2.11^{\mathrm{a}}$ & $1.83^{\mathrm{b}}$ \\
\hline \multirow[t]{2}{*}{ Odour } & Male (44) & $1.59^{\mathrm{a}}$ & $1.66^{\mathrm{a}}$ & $1.73^{\mathrm{b}}$ & $1.66^{\mathrm{a}}$ & $1.64^{\mathrm{a}}$ & $1.66^{\mathrm{a}}$ & $1.66^{\mathrm{a}}$ & $1.68^{\mathrm{a}}$ \\
\hline & Female (36) & $1.53^{\mathrm{a}}$ & $1.50^{\mathrm{a}}$ & $1.58^{\mathrm{b}}$ & $1.56^{\mathrm{b}}$ & $1.64^{\mathrm{c}}$ & $1.67^{\mathrm{c}}$ & $1.56^{\mathrm{b}}$ & $1.47^{\mathrm{a}}$ \\
\hline
\end{tabular}

Different superscript in a row means significant differences $(\mathrm{P}<0.05)$ between groups

Table $1 b$. Sensory evaluation of Wiener sausage

\begin{tabular}{|c|c|c|c|c|c|c|c|c|}
\hline & \multicolumn{8}{|c|}{ Occupation of consumers } \\
\hline & $\begin{array}{l}\text { Sheep } \\
\text { farmer }\end{array}$ & $\begin{array}{c}\text { Other } \\
\text { animal } \\
\text { farming }\end{array}$ & $\begin{array}{c}\text { Other } \\
\text { agriculture }\end{array}$ & $\begin{array}{l}\text { Industry, } \\
\text { catering }\end{array}$ & Education & Student & $\begin{array}{l}\text { Administ- } \\
\text { rative } \\
\text { department } \\
\text { of state }\end{array}$ & $\begin{array}{c}\text { Other } \\
\text { profession }\end{array}$ \\
\hline $\mathrm{n}$ & 9 & 7 & 12 & 25 & 2 & 8 & 7 & 10 \\
\hline Stringiness & $2.71^{\mathrm{a}}$ & $2.25^{\mathrm{b}}$ & $2.56^{\mathrm{a}}$ & $2.65^{\mathrm{a}}$ & $2.56^{\mathrm{ab}}$ & $2.83^{\mathrm{a}}$ & $2.96^{\mathrm{ac}}$ & $2.30^{\mathrm{b}}$ \\
\hline Flavour & $2.36^{\mathrm{a}}$ & $1.82^{\mathrm{b}}$ & $2.24^{\mathrm{ac}}$ & $2.13^{\mathrm{a}}$ & $1.81^{\mathrm{b}}$ & $1.98^{\mathrm{bc}}$ & $2.02^{\mathrm{bc}}$ & $2.05^{\mathrm{b}}$ \\
\hline \multirow[t]{3}{*}{ Odour } & $1.79^{\mathrm{a}}$ & $1.61^{\mathrm{ab}}$ & $1.70^{\mathrm{ac}}$ & $1.42^{\mathrm{b}}$ & $1.50^{\mathrm{ab}}$ & $1.45^{\mathrm{b}}$ & $1.54^{\mathrm{bc}}$ & $1.61^{\mathrm{bc}}$ \\
\hline & \multicolumn{8}{|c|}{ Age of consumers } \\
\hline & $\begin{array}{c}\text { Under } \\
\text { year } 20\end{array}$ & $\begin{array}{c}21-30 \\
\text { years }\end{array}$ & $\begin{array}{l}31-40 \\
\text { years }\end{array}$ & $\begin{array}{l}41-50 \\
\text { years }\end{array}$ & $\begin{array}{l}51-60 \\
\text { years }\end{array}$ & $\begin{array}{l}61-70 \\
\text { years }\end{array}$ & $\begin{array}{l}\text { Above } \\
70 \text { years }\end{array}$ & \\
\hline $\mathrm{n}$ & 4 & 13 & 10 & 10 & 20 & 19 & 4 & \\
\hline Stringiness & $2.09^{\mathrm{a}}$ & $2.46^{\mathrm{bd}}$ & $2.49^{\text {bd }}$ & $2.80^{\mathrm{c}}$ & $2.54^{\mathrm{d}}$ & $2.57^{\mathrm{bcd}}$ & $2.38^{\mathrm{abd}}$ & \\
\hline Flavour & $1.75^{\mathrm{a}}$ & $2.26^{\mathrm{bc}}$ & $2.01^{\mathrm{ac}}$ & $2.25^{\mathrm{bc}}$ & $1.94^{\mathrm{ac}}$ & $2.03^{\mathrm{ac}}$ & $2.22^{\mathrm{c}}$ & \\
\hline Odour & $1.75^{\mathrm{a}}$ & $1.66^{\mathrm{a}}$ & $1.61^{\mathrm{a}}$ & $1.63^{\mathrm{a}}$ & $1.50^{\mathrm{b}}$ & $1.73^{\mathrm{ac}}$ & $1.34^{\mathrm{c}}$ & \\
\hline
\end{tabular}

Different superscript in a row means significant differences $(\mathrm{P}<0.05)$ between groups

catering, administrative department, and students and of other profession were significantly different from the of the shepherds.

It seemed that the age of panellists essentially influenced scores regarding stringiness and flavour. The young under 20 years gave the best (lowest) scores to stringiness and flavour, and the worst (highest) to the odour of sausage. The judgements of older panellists fundamentally differed from scores given by younger panel members in odour, as to the latter ones lamb meat was dominantly unfamiliar. 


\subsection{Cured, smoked, and cooked lamb ham (Table 2)}

There were significant differences among genotypes in stringiness, flavour, and odour. In all three traits differences were observed between opinions of male and female panellists. When comparing breeds (genotypes), significant differences could be observed as in the studies of FAHMY and co-workers (1992), Bunch and co-workers (2004), and TeIXeIRA and co-workers (2005).

Table $2 a$. Sensory evaluation of ham

\begin{tabular}{|c|c|c|c|c|c|c|c|c|c|}
\hline & \multirow[b]{2}{*}{$\begin{array}{l}\text { Gender of } \\
\text { consumer } \\
\text { (n) }\end{array}$} & \multicolumn{8}{|c|}{ Breed } \\
\hline & & $\begin{array}{c}\text { Tran- } \\
\text { sylvanian } \\
\text { Racka }\end{array}$ & $\begin{array}{c}\text { British } \\
\text { Milk- } \\
\text { sheep } \\
\mathrm{F}_{1}\end{array}$ & $\begin{array}{c}\text { Charollais } \\
\mathrm{F}_{1}\end{array}$ & $\begin{array}{c}\text { Ile de } \\
\text { France } \\
F_{1}\end{array}$ & $\begin{array}{c}\text { German } \\
\text { Blackhead } \\
\text { Mutton } \\
\text { Sheep } \\
F_{1}\end{array}$ & $\begin{array}{c}\text { German } \\
\text { Mutton } \\
\text { Merino } \\
\mathrm{F}_{1}\end{array}$ & $\begin{array}{c}\text { Suffolk } \\
\mathrm{F}_{1}\end{array}$ & $\begin{array}{c}\text { Texel } \\
\mathrm{F}_{1}\end{array}$ \\
\hline \multirow[t]{2}{*}{ Stringiness } & Male (50) & $2.32^{\mathrm{a}}$ & $2.24^{\mathrm{b}}$ & $2.38^{\mathrm{c}}$ & $2.31^{\mathrm{b}}$ & $2.26^{\mathrm{b}}$ & $2.34^{\mathrm{a}}$ & $2.40^{\mathrm{c}}$ & $2.14^{\mathrm{b}}$ \\
\hline & Female (32) & $2.34^{\mathrm{a}}$ & $2.13^{\mathrm{b}}$ & $2.50^{c}$ & $2.06^{\mathrm{b}}$ & $1.91 \mathrm{~d}$ & $2.25^{\mathrm{b}}$ & $2.09^{\mathrm{b}}$ & $2.16^{\mathrm{b}}$ \\
\hline \multirow[t]{2}{*}{ Flavour } & Male (50) & $2.14^{\mathrm{a}}$ & $2.08^{\mathrm{a}}$ & $1.92^{\mathrm{b}}$ & $2.04^{\mathrm{a}}$ & $1.94^{\mathrm{b}}$ & $2.14^{\mathrm{a}}$ & $2.12^{\mathrm{a}}$ & $1.92^{\mathrm{b}}$ \\
\hline & Female (32) & $2.38^{\mathrm{a}}$ & $2.13^{\mathrm{b}}$ & $2.19^{\mathrm{b}}$ & $2.06^{\mathrm{b}}$ & $1.69^{\mathrm{c}}$ & $1.84^{\mathrm{c}}$ & $2.00^{\mathrm{b}}$ & $1.72^{\mathrm{c}}$ \\
\hline \multirow[t]{2}{*}{ Odour } & Male (50) & $1.66^{\mathrm{a}}$ & $1.62^{\mathrm{a}}$ & $1.62^{\mathrm{a}}$ & $1.51^{\mathrm{b}}$ & $1.46^{\mathrm{b}}$ & $1.64^{\mathrm{a}}$ & $1.72^{\mathrm{c}}$ & $1.58^{\mathrm{b}}$ \\
\hline & Female (32) & $1.56^{\mathrm{a}}$ & $1.50^{\mathrm{a}}$ & $1.69^{\mathrm{b}}$ & $1.34^{\mathrm{b}}$ & $1.31^{\mathrm{b}}$ & $1.50^{\mathrm{a}}$ & $1.59^{\mathrm{a}}$ & $1.34^{\mathrm{c}}$ \\
\hline
\end{tabular}

Different superscript in a row means significant differences $(\mathrm{P}<0.05)$ between groups

Table $2 b$. Sensory evaluation of ham

\begin{tabular}{|c|c|c|c|c|c|c|c|c|}
\hline & \multicolumn{8}{|c|}{ Occupation of consumers } \\
\hline & $\begin{array}{l}\text { Sheep } \\
\text { farmer }\end{array}$ & $\begin{array}{c}\text { Other } \\
\text { animal } \\
\text { farming }\end{array}$ & $\begin{array}{c}\text { Other } \\
\text { agriculture }\end{array}$ & $\begin{array}{l}\text { Industry, } \\
\text { catering }\end{array}$ & Education & Student & $\begin{array}{l}\text { Administ- } \\
\text { rative } \\
\text { depart- } \\
\text { ment of } \\
\text { state }\end{array}$ & $\begin{array}{c}\text { Other } \\
\text { profession }\end{array}$ \\
\hline $\mathrm{n}$ & 7 & 12 & 21 & 27 & 3 & 4 & 4 & 4 \\
\hline Stringiness & $2.59^{\mathrm{a}}$ & $2.15^{\mathrm{bc}}$ & $2.35^{\mathrm{ab}}$ & $2.06^{\mathrm{bc}}$ & $2.42^{\mathrm{abc}}$ & $2.13^{\mathrm{bc}}$ & $2.00^{c}$ & $2.11^{\mathrm{c}}$ \\
\hline Flavour & $2.36^{\mathrm{a}}$ & $2.00^{\mathrm{b}}$ & $2.07^{\mathrm{b}}$ & $2.00^{\mathrm{b}}$ & $2.13^{\mathrm{ab}}$ & $1.84^{\mathrm{b}}$ & $1.94^{\mathrm{b}}$ & $1.90^{\mathrm{b}}$ \\
\hline \multirow[t]{3}{*}{ Odour } & $2.02^{\mathrm{a}}$ & $1.49^{\text {bd }}$ & $1.67^{\mathrm{c}}$ & $1.50^{\mathrm{bcd}}$ & $1.67^{\mathrm{bc}}$ & $1.38^{\mathrm{bd}}$ & $1.41^{\mathrm{bd}}$ & $1.34^{\mathrm{d}}$ \\
\hline & \multicolumn{8}{|c|}{ Age of consumers } \\
\hline & $\begin{array}{c}\text { Under } \\
\text { year } 20\end{array}$ & $\begin{array}{l}21-30 \\
\text { years }\end{array}$ & $\begin{array}{l}31-40 \\
\text { years }\end{array}$ & $\begin{array}{l}41-50 \\
\text { years }\end{array}$ & $\begin{array}{l}51-60 \\
\text { years }\end{array}$ & $\begin{array}{l}61-70 \\
\text { years }\end{array}$ & $\begin{array}{l}\text { Above } \\
70 \text { years }\end{array}$ & \\
\hline $\mathrm{n}$ & 6 & 11 & 13 & 12 & 21 & 14 & 5 & \\
\hline Stringiness & $2.38^{\mathrm{abc}}$ & $2.61^{\mathrm{a}}$ & $2.28^{\mathrm{bc}}$ & $2.39^{\mathrm{ab}}$ & $2.15^{\mathrm{c}}$ & $2.13^{\mathrm{c}}$ & $1.70^{\mathrm{d}}$ & \\
\hline Flavour & $2.08^{\mathrm{ab}}$ & $2.23^{\mathrm{a}}$ & $2.13^{\mathrm{ab}}$ & $1.94^{\mathrm{b}}$ & $2.02^{\mathrm{ab}}$ & $1.98^{\mathrm{b}}$ & $1.58^{\mathrm{c}}$ & \\
\hline Odour & $1.67^{\mathrm{ac}}$ & $1.78^{\mathrm{a}}$ & $1.40^{\text {bd }}$ & $1.49^{\mathrm{cd}}$ & $1.42^{\mathrm{d}}$ & $1.80^{\mathrm{a}}$ & $1.33^{\mathrm{d}}$ & \\
\hline
\end{tabular}

Different superscript in a row means significant differences $(\mathrm{P}<0.05)$ between groups 
There were significant differences between shepherds and other occupation groups. This tendency could also be observed in odour; however, judgements of the other agriculture group were closer to shepherds, than to other animal farmers. The sheep farmers were the most critical, as they found the ham the most stringy, less delicious, and with most insufficient odour.

The age of panellists had strong effect on scores in stringiness and flavour. The judgements of age category 21-30 and above 70 years definitely deviated from scores given by others. The people above 70 years gave the best (lowest) scores to ham in all three traits. In odour significant differences were observed among the two oldest panellist groups, as they gave the best (above 70 years) and the worst (61-70 years) scores.

\subsection{Kitchen ready, seasoned, cured, sliced, roasted lamb meat (Table 3)}

Greater degree of differences were observed among genotypes in stringiness and to a less extent in flavour, while concerning odour smaller deviations were found. The flavour of roasted meat from German Blackhead Mutton $\mathrm{F}_{1}$ was the worst scored among genotypes by both men and women, while women also found this meat the most stringy and its odour the least satisfying among genotypes. The men preferred the roasted meat made from Ile de France $F_{1}$ lambs, giving the lowest scores to all three traits, however, women gave the best scores for stringiness and flavour of Charollais $F_{1}$ meat and odour of Texel $F_{1}$ meat. At the same time, there were significant breed (genotype) differences among the scores as was also mentioned by Duckett and Kuber (2001), HoffMAN and co-workers (2003), and Brzostowski and co-workers (2004).

The occupation of panellists had less determining effect on stringiness and flavour concerning Wiener sausages. On the contrary, there were large differences among occupation groups concerning odour. Sheep farmers gave the worst (highest) scores for meat, as for ham, probably, because they preferred the stronger sheep meat taste.

Studying age, panellists under 20 years gave the best (lowest) scores in all three traits, while the 21-30 years old panellists found the meat the most stringy and less delicious, and 61-70 years old panellists the least sufficient odour among age groups.

Table $3 a$. Sensory evaluation of roasted meat

\begin{tabular}{|c|c|c|c|c|c|c|c|c|c|}
\hline & \multirow[b]{2}{*}{$\begin{array}{l}\text { Gender of } \\
\text { consumer } \\
\text { (n) }\end{array}$} & \multicolumn{8}{|c|}{ Breed } \\
\hline & & $\begin{array}{c}\text { Tran- } \\
\text { sylvanian } \\
\text { Racka }\end{array}$ & $\begin{array}{l}\text { British } \\
\text { Milk- } \\
\text { sheep } \\
\mathrm{F}_{1}\end{array}$ & $\begin{array}{c}\text { Charollais } \\
\qquad \mathrm{F}_{1}\end{array}$ & $\begin{array}{c}\text { Ile de } \\
\text { France } \\
\mathrm{F}_{1}\end{array}$ & $\begin{array}{c}\text { German } \\
\text { Blackhead } \\
\text { Mutton } \\
\text { Sheep } \\
\mathrm{F}_{1} \\
\end{array}$ & $\begin{array}{l}\text { German } \\
\text { Mutton } \\
\text { Merino } \\
\mathrm{F}_{1}\end{array}$ & $\begin{array}{c}\text { Suffolk } \\
\mathrm{F}_{1}\end{array}$ & $\begin{array}{c}\text { Texel } \\
\mathrm{F}_{1}\end{array}$ \\
\hline \multirow[t]{2}{*}{ Stringiness } & Mate (37) & $2.38^{\mathrm{a}}$ & $2.38^{\mathrm{a}}$ & $2.24^{\mathrm{b}}$ & $2.03^{c}$ & $2.38^{\mathrm{a}}$ & $2.54 \mathrm{~d}$ & $2.35^{\mathrm{a}}$ & $2.32^{\mathrm{a}}$ \\
\hline & Femª (27) & $2.37^{\mathrm{a}}$ & $2.39^{\mathrm{a}}$ & $2.04^{\mathrm{b}}$ & $2.22^{\mathrm{b}}$ & $2.78^{\mathrm{c}}$ & $2.41^{\mathrm{a}}$ & $2.37^{\mathrm{a}}$ & $2.44^{\mathrm{a}}$ \\
\hline \multirow[t]{2}{*}{ Flavour } & $M^{\mathrm{a}}$ le (37) & $1.86^{\mathrm{a}}$ & $1.97^{\mathrm{b}}$ & $1.81^{\mathrm{a}}$ & $1.76^{\mathrm{c}}$ & $2.00^{\mathrm{b}}$ & $1.76^{\mathrm{c}}$ & $1.89^{\mathrm{a}}$ & $1.84^{\mathrm{a}}$ \\
\hline & Femª le (27) & $1.85^{\mathrm{a}}$ & $2.04^{\mathrm{b}}$ & $1.85^{\mathrm{a}}$ & $2.04^{\mathrm{b}}$ & $2.19^{c}$ & $1.96^{\mathrm{a}}$ & $2.04^{\mathrm{b}}$ & $1.89^{\mathrm{a}}$ \\
\hline \multirow[t]{2}{*}{ Odour } & 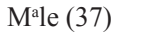 & $1.41^{\mathrm{a}}$ & $1.49^{\mathrm{b}}$ & $1.46^{\mathrm{b}}$ & $1.38^{\mathrm{a}}$ & $1.41^{\mathrm{a}}$ & $1.59^{c}$ & $1.54^{\mathrm{c}}$ & $1.46^{\mathrm{b}}$ \\
\hline & Femª (27) & $1.59^{\mathrm{a}}$ & $1.67^{\mathrm{b}}$ & $1.56^{\mathrm{a}}$ & $1.70^{\mathrm{b}}$ & $1.89^{\mathrm{c}}$ & $1.63^{\mathrm{b}}$ & $1.52^{\mathrm{a}}$ & $1.41^{\mathrm{a}}$ \\
\hline
\end{tabular}

Different superscript in a row means significant differences $(\mathrm{P}<0.05)$ between groups 
Table $3 b$. Sensory evaluation of roasted meat

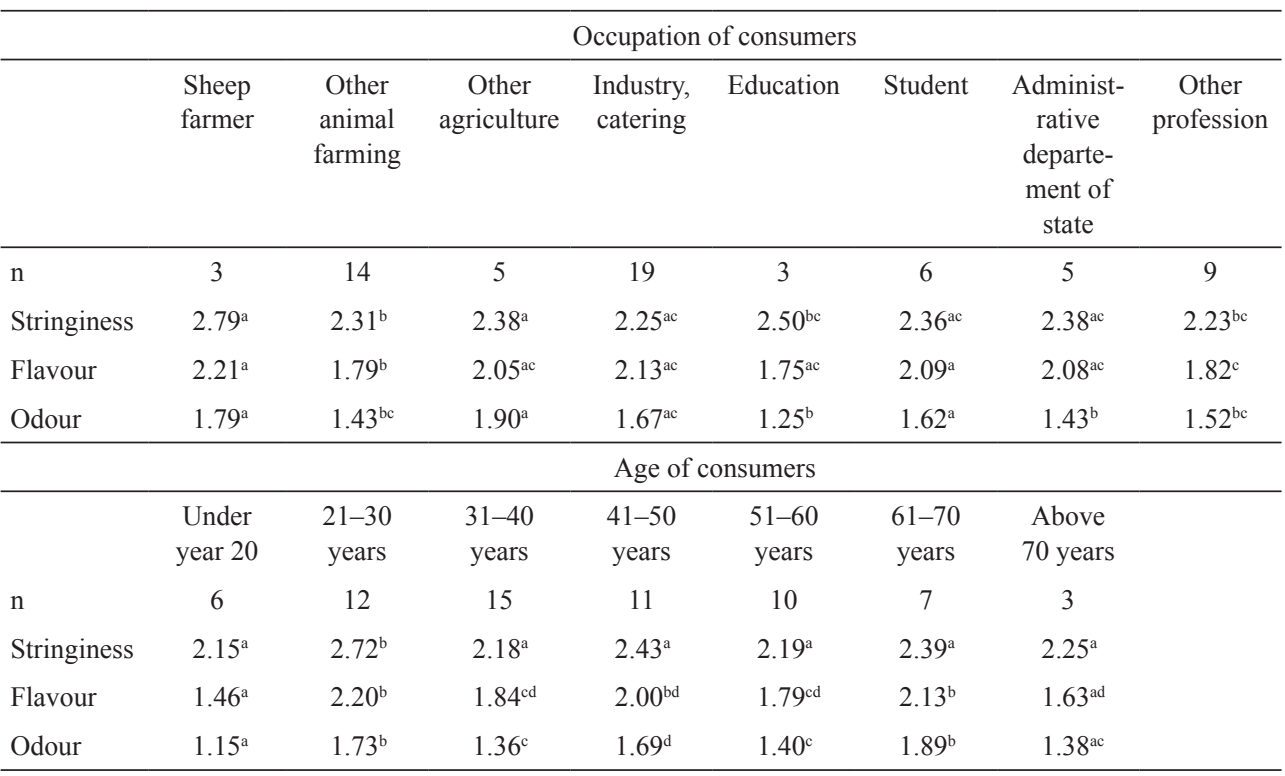

Different superscript in a row means significant differences $(\mathrm{P}<0.05)$ between groups

\subsection{Whole roasted lamb leg (restaurant style) (Table 4)}

Differences among genotypes could also be followed in this product concerning all three quality traits. The roasted leg of Transylvanian purebred lambs were found to be the best among genotypes by both men and women. However, men preferred the flavour of Charollais $\mathrm{F}_{1}$ lamb leg, this meat was scored the most stringy. The flavour of British Milk sheep $\mathrm{F}_{1}$ lamb leg was less delicious than legs of other genotypes. Apart from those there were no significant differences among breeds as in some previously mentioned studies.

Table 4a. Sensory evaluation of roasted leg

\begin{tabular}{|c|c|c|c|c|c|c|c|c|c|}
\hline & \multirow[b]{2}{*}{$\begin{array}{l}\text { Gender of } \\
\text { consumer } \\
\text { (n) }\end{array}$} & \multicolumn{8}{|c|}{ Breed } \\
\hline & & $\begin{array}{c}\text { Tran- } \\
\text { sylvanian } \\
\text { Racka }\end{array}$ & $\begin{array}{l}\text { British } \\
\text { Milk- } \\
\text { sheep } \\
\mathrm{F}_{1}\end{array}$ & $\begin{array}{c}\text { Charollais } \\
\mathrm{F}_{1}\end{array}$ & $\begin{array}{c}\text { Ile de } \\
\text { France } \\
\mathrm{F}_{1}\end{array}$ & $\begin{array}{c}\text { German } \\
\text { Blackhead } \\
\text { Mutton } \\
\text { Sheep } \\
\mathrm{F}_{1} \\
\end{array}$ & $\begin{array}{c}\text { German } \\
\text { Mutton } \\
\text { Merino } \\
\mathrm{F}_{1}\end{array}$ & $\begin{array}{c}\text { Suffolk } \\
\mathrm{F}_{1}\end{array}$ & $\begin{array}{c}\text { Texel } \\
\mathrm{F}_{1}\end{array}$ \\
\hline \multirow[t]{2}{*}{ Stringiness } & Male (27) & $2.07^{\mathrm{a}}$ & $2.11^{\mathrm{a}}$ & $2.78^{\mathrm{b}}$ & - & - & - & - & $2.22^{\mathrm{c}}$ \\
\hline & Female (12) & $2.00^{\mathrm{a}}$ & $2.08^{\mathrm{a}}$ & $3.17^{\mathrm{b}}$ & - & - & - & - & $2.83^{\mathrm{c}}$ \\
\hline \multirow[t]{2}{*}{ Flavour } & Male (27) & $2.11^{\mathrm{a}}$ & $2.48^{\mathrm{b}}$ & $2.00^{\mathrm{a}}$ & - & - & - & - & $2.22^{\mathrm{c}}$ \\
\hline & Female (12) & $1.92^{\mathrm{a}}$ & $2.75^{\mathrm{b}}$ & $2.50^{c}$ & - & - & - & - & $2.42^{\mathrm{d}}$ \\
\hline \multirow[t]{2}{*}{ Odour } & Male (27) & $1.08^{\mathrm{a}}$ & $2.07^{\mathrm{b}}$ & $1.81^{\mathrm{c}}$ & - & - & - & - & $1.84^{\mathrm{c}}$ \\
\hline & Female (12) & $1.25^{\mathrm{a}}$ & $1.75^{b}$ & $1.83^{\mathrm{b}}$ & - & - & - & - & $2.00^{\mathrm{c}}$ \\
\hline
\end{tabular}

Different superscript in a row means significant differences $(\mathrm{P}<0.05)$ between groups 
Table $4 b$. Sensory evaluation of roasted leg

\begin{tabular}{|c|c|c|c|c|c|c|c|c|}
\hline & \multicolumn{8}{|c|}{ Occupation of consumers } \\
\hline & $\begin{array}{l}\text { Sheep } \\
\text { farmer }\end{array}$ & $\begin{array}{c}\text { Other } \\
\text { animal } \\
\text { farming }\end{array}$ & $\begin{array}{c}\text { Other } \\
\text { agriculture }\end{array}$ & $\begin{array}{l}\text { Industry, } \\
\text { catering }\end{array}$ & Education & Student & $\begin{array}{l}\text { Administ- } \\
\text { rative } \\
\text { depart- } \\
\text { ment of } \\
\text { state }\end{array}$ & $\begin{array}{c}\text { Other } \\
\text { profession }\end{array}$ \\
\hline $\mathrm{n}$ & 10 & 9 & 4 & & 3 & 3 & 5 & 5 \\
\hline Stringiness & $2.42^{\mathrm{a}}$ & $2.41^{\mathrm{a}}$ & $2.00^{\mathrm{ab}}$ & - & $1.38^{\mathrm{b}}$ & $2.63^{\mathrm{a}}$ & $2.50^{\mathrm{a}}$ & $2.35^{\mathrm{a}}$ \\
\hline Flavour & $2.52^{\mathrm{a}}$ & $2.09^{\mathrm{b}}$ & $2.00^{\mathrm{abc}}$ & - & $1.13^{\mathrm{c}}$ & $3.00^{\mathrm{a}}$ & $2.30^{\mathrm{ad}}$ & $2.15^{\mathrm{ad}}$ \\
\hline \multirow[t]{3}{*}{ Odour } & $1.96^{\mathrm{a}}$ & $1.68^{\mathrm{b}}$ & $1.25^{\mathrm{b}}$ & - & $1.50^{\mathrm{ab}}$ & $1.88^{\mathrm{ab}}$ & $1.60^{\mathrm{b}}$ & $1.80^{\mathrm{ab}}$ \\
\hline & \multicolumn{8}{|c|}{ Age of consumers } \\
\hline & $\begin{array}{c}\text { under year } \\
20\end{array}$ & $\begin{array}{l}21-30 \\
\text { years }\end{array}$ & $\begin{array}{l}31-40 \\
\text { years }\end{array}$ & $\begin{array}{l}41-50 \\
\text { years }\end{array}$ & $\begin{array}{l}51-60 \\
\text { years }\end{array}$ & $\begin{array}{l}61-70 \\
\text { years }\end{array}$ & $\begin{array}{c}\text { above } \\
70 \text { years }\end{array}$ & \\
\hline $\mathrm{n}$ & & 7 & 6 & 8 & 11 & 7 & & \\
\hline Stringiness & - & $2.30^{\mathrm{a}}$ & $2.13^{\mathrm{a}}$ & $2.56^{\mathrm{a}}$ & $2.45^{\mathrm{a}}$ & $2.19^{\mathrm{a}}$ & - & \\
\hline Flavour & - & $2.60^{\mathrm{a}}$ & $1.75^{\mathrm{b}}$ & $2.75^{\mathrm{a}}$ & $2.20^{\mathrm{ab}}$ & $1.94^{\mathrm{b}}$ & - & \\
\hline Odour & - & $1.80^{\mathrm{a}}$ & $1.75^{\mathrm{a}}$ & $2.06^{\mathrm{ab}}$ & $1.70^{\mathrm{ac}}$ & $1.59^{\mathrm{ac}}$ & - & \\
\hline
\end{tabular}

Different superscript in a row means significant differences $(\mathrm{P}<0.05)$ between groups

Comparing occupation groups, students found this product the most stringy and the least delicious, opposed to panellist working in education. The odour was observed the best by panellist working in other agriculture sector.

Among age groups, the worst scores were given by 41-50 years old panellists for all three traits, while the 31-40 years old panellists found the lamb leg the softest and most delicious among all age groups. The most sufficient odour was observed by 61-70 years old panellists. In stringiness the differences were not significant, while in flavour definite age group differences were observed. Concerning odour scores, groups above 40 years were significantly different from lower age groups.

\section{Conclusions}

The general acceptance of the various lamb meat foods was far beyond expectation; the acceptance of lamb meat could be improved by introducing new kinds of foods. Strong differences could be found in the evaluations of stringiness, flavour, and odour according to the gender of the panellists. Women gave better scores to odour, because they have less bad experience, as they consume sheep meat less frequently.

The age and the occupation of the panellists have significant effect on the score given to various foods, as their preference and knowledge about various meats were different. There were significant differences among the panellists in the evaluation of stringiness, flavour, and odour. The panellists were able to distinguish between the various breeds (genotypes) in the evaluation of foods. 
This paper presents a part of the results within the project GVOP-3.3.1.-2004 "Bio-juhhús termelés fejlesztése" (Development of bio lamb meat production), financed by the National Research and Technology Office, Hungary.

\section{References}

Beriain, M.J., Horcada, A., Purroy, A., Lizaso, G., Chasco, J. \& Mendizabal, J.A. (2000): Characteristics of Lacha and Rasa Aragonesa lambs slaughtered at three live weights. J. Anim. Sci., 78, 3070-3077.

Brzostowski, H., Tywonczuk, J. \& TANSKI, Z. (2004): Indexes of nutritive value of meat obtained from Pomeranian lambs and crossbreeds of Pomeranian ewes with meat breed rams. Arch. Tierz., 47, 175-182.

Bunch, T.D., Evans, R.C., Wang, S., Brennand, C.P., WhitTier D.R. \& TaYlor, B.J. (2004): Feed efficiency, growth rates, carcass evaluation, cholesterol level and sensory evaluation of lambs of various hair and wool sheep and their crosses. Small Rum. Res., 52, 239-245.

Duckett, S.K. \& Kuber, P.S. (2001): Genetic and nutritional effects on lamb flavour. J. Anim. Sci., 79, $249-259$.

Dryden, F.D. \& MARChello, J.A. (1970): Influence of total lipid and fatty acid composition upon the palatability of three bovine muscles. J. Anim. Sci., 31, 36-41.

Fahmy, M.H., Boucher, J.M., Poste, L.M., Gregoire, R., Butler, G. \& Comeau, J.E. (1992): Feed efficiency, carcass characteristics, and sensory quality of lambs, with or without prolific ancestry, fed diets with different protein supplements. J. Anim. Sci., 70, 1365-1374.

Fisher, A.V., Enser, M., Richardson, R.I., Wood, J.D., Nute, G.R., Kurt, E., Sinclair, L.A. \& Wilkinson, R.G. (2000): Fatty acid composition and eating quality of lamb types derived from four diverse breed $x$ production systems. Meat Sci., 55, 141-147.

Gorraiz, C., Beriain, M.J., Chasco, J. \& Iraizoz, M. (2000): Descriptive analysis of meat from young ruminants in Mediterranean systems. J. Sens. Stud., 15, 137-150.

Hoffman, L.C., Muller, M., Cloete, S.W.P. \& Schmidt, D. (2003): Comparison of six crossbred lamb types: sensory, physical and nutritional meat quality characteristics. Meat Sci., 65, 1265-1274.

Horcada, A., Berian, M.J., Purroy, A., Lizaso, G. \& Chasco, J. (1998): Effect of sex on the quality of Spanish lamb breeds (Lacha and Rasa Aragonese). Animal Sci., 67, 541-547.

Lind, V., Berg, J, Eilertsen, S.M., Hersleth, M. \& Eik, L.O. (2011): Effect of gender on meat quality in lamb from extensive and intensive grazing systems when slaughtered at the end of the growing season. Meat Sci., 88 , $305-310$.

Melton, S. (1990): Effects of feeds on flavour of red meat - a review. J. Animal Sci., 68, 4421-4435.

Mushi, D.E., Eik, L.O., Sørheim, O., Ádnøy, T., \& Haugen, J.E. (2008): Effect of sex of animals and time of slaughter on sensory quality of meat from Norwegian lambs. Acta Agric. Scand. Section A, 58, 31-36.

Notter, D.R., Kelly, R.F., \& Berry, B.W. (1991): Effects of ewe breed and management system on efficiency of lamb production: III. Meat characteristics. J. Animal Sci., 69, 3523-3532.

Rousset-Akrim, S., Young, O.A., \& Berdaguè, J.L. (1997): Diet and growth effects in panel assessment of sheep meat odour and flavour. Meat Sci., 45, 169-181.

Sañudo, C., Campo, M.M., Sierra, I., María, G.A., Olleta, J.L. \& Santolaria, P. (1997): Breed effect on carcass and meat quality of suckling lambs. Meat Sci., 46, 357-365.

Sañudo, C., Nute, G.R., Campo, M.M., María, G., Baker, A., Sierra, I., Enser, M.E. \& Wood, J.D. (1998): Assessment of commercial lamb meat quality by British and Spanish taste panels. Meat Sci., 52, 195-202.

Sañudo, C., Enser, M.E., Campo, M.M., Nute, G.R., Maria, G., Sierra, I., \& Wood, J.D. (2000): Fatty acid composition and sensory characteristics of lamb carcasses from Britain and Spain. Meat Sci., 54, 339-346.

Teixeira, A., Batista, S., Delfa, R. \& Cadavez, V. (2005): Lamb meat quality of two breeds with protected origin designation. Influence of breed, sex and live weight. Meat Sci., 71, 530-536.

Ward, C.E., Trent, A. \& Hildebrand, J.L. (1995): Consumer perceptions of lamb compared with other meats. Sheep Goat Res. J., 11, 64-70. 